\title{
Oxidation of Naphthalene by Cyanobacteria and Microalgae
}

\author{
By CARL E. CER NIGLIA, ${ }^{1}$ DAVID T. GIBSON ${ }^{1 *}$ \\ AND CHASE VAN BAALEN ${ }^{2}$ \\ ${ }^{1}$ Department of Microbiology, The University of Texas at Austin, \\ Austin, Texas 78712 , U.S.A. \\ ${ }^{2}$ The University of Texas Marine Science Institute, \\ Port Aransas Marine Laboratory, Port Aransas, Texas 78373, U.S.A.
}

(Received 19 April 1979; revised 20 July 1979)

Eighteen different algal cultures were examined for their ability to metabolize naphthalene. The strains tested included nine cyanobacteria (blue-green algae), five green algae, one red alga and one brown alga; two diatoms were also examined. All these organisms oxidized naphthalene under photoautotrophic conditions. Experiments with $\left[{ }^{14} \mathrm{C}\right]$ naphthalene showed that each organism oxidized naphthalene to at least six metabolites. One of the metabolites was identified as 1-naphthol. Under the experimental conditions used in this study the extent of naphthalene metabolism to organic-soluble derivatives ranged from $0 \cdot 1$ to $2 \cdot 4 \%$.

\section{INTRODUCTION}

In recent years there has been increasing concern over the fate of aromatic hydrocarbons in marine ecosystems since several of these compounds are known to exhibit toxic, mutagenic and carcinogenic properties (Daly et al., 1972). Since naphthalene is a major component in the water-soluble fraction of crude and certain fuel oils (Winters et al., 1976), we decided to investigate naphthalene oxidation by a variety of cyanobacteria and microalgae.

Recently, we have reported that the cyanobacteria Agmenellum quadruplicatum, strain PR-6 and Oscillatoria sp., strain JCM oxidize naphthalene to 1-naphthol as the major product (Cerniglia et al., 1979, 1980). The results described in this paper suggest that the ability to oxidize naphthalene is widely distributed amongst the algae.

\section{METHODS}

Organism and growth conditions. Sources of algae, the growth media and growth temperatures are listed in Table 1. Metabolic studies were conducted in a 'closed flask' growth system as previously described (Cerniglia et al., 1979, 1980).

Detection and quantification of naphthalene metabolites. After $24 \mathrm{~h}$ incubation, products formed by the metabolism of naphthalene were recovered as described previously (Cerniglia et al., 1979, 1980). Each residue was redissolved in $0.1 \mathrm{ml}$ acetone and samples $(20 \mu \mathrm{l})$ were applied to a silica gel $60 \mathrm{~F}_{254}$ glass plate (E. Merck, Darmstadt, Germany). The chromatogram was developed three times in chloroform/acetone $(8: 2, \mathrm{v} / \mathrm{v})$. Multiple development was necessary for the separation of cis-1,2-dihydroxy-1,2-dihydronaphthalene (cis-naphthalene dihydrodiol) from its trans-isomer. Naphthalene metabolites were located on chromatograms by viewing under ultraviolet light $(254 \mathrm{~nm})$ and also by spraying with Gibb's reagent [2,6-dichloroquinone-4-chloroimide in methanol $(2 \%, \mathrm{w} / \mathrm{v})]$.

Metabolism of $\left[{ }^{14} \mathrm{C}\right]$ naphthalene. Incubations were carried out as described above except that $\left[1-{ }^{14} \mathrm{C}\right]-$ naphthalene [ $35 \mu \mathrm{g}, 1.0 \mu \mathrm{Ci}(37 \mathrm{kBq})$ in $0.1 \mathrm{ml} 95 \%$ ethanol] was used as the substrate. All culture volumes were $30 \mathrm{ml}$.

Detection of ${ }^{14} \mathrm{C}$-labelled metabolites. Samples were prepared for chromatography as described above for experiments with unlabelled naphthalene. The radioactive extracts $(20 \mu \mathrm{l})$ were applied to the base of a plastic thin-layer chromatography plate (Polygram Sil G/UV ${ }_{254}$; Machery-Nagel \& Co., Duren, Germany). 
Table 1. Source and growth conditions of various cyanobacteria and microalgae examined for their ability to metabolize naphthalene

\begin{tabular}{|c|c|c|}
\hline Organism & $\begin{array}{c}\text { Growth } \\
\text { conditions* }\end{array}$ & Sourcet \\
\hline \multicolumn{3}{|l|}{ Cyanobacteria } \\
\hline Oscillatoria sp. strain JCM & 2 & C. Van Baalen \\
\hline Oscillatoria sp. strain MEV & 2 & C. Van Baalen \\
\hline Microcoleus chthonoplastes strain BA-1 & 2 & C. Van Baalen \\
\hline Anabaena sp. strain CA & 1 & C. Van Baalen \\
\hline Anabaena sp. strain $1 \mathrm{~F}$ & 1 & C. Van Baalen \\
\hline Agmenellum quadruplicatum strain PR-6 & 2 & C. Van Baalen \\
\hline Coccochloris elabens strain $17 \mathrm{a}$ & 2 & C. Van Baalen \\
\hline Nostoc sp. strain MAC & 7 & D. S. Hoare (available from C.V.B.) \\
\hline Aphanocapsa sp. strain 6714 & 6 & R. Rippka \\
\hline \multicolumn{3}{|l|}{ Green algae } \\
\hline Chlorella sorokiniana strain TX 71105 & 7 & J. Myers \\
\hline Chlorella autotrophica strain 580 & 4 & R. R. Guillard \\
\hline Dunaliella tertiolecta strain DUN & 4 & R. R. Guillard \\
\hline Chlamydomonas angulosa & 6 & J. A. Hellebust \\
\hline Ulva fasciata & 8 & Field collected, Port Aransas, Tex., U.S.A. \\
\hline \multicolumn{3}{|l|}{ Diatoms } \\
\hline Cylindrotheca sp., strain N-1 & 5 & C. Van Baalen \\
\hline Amphora sp., strain AMP-1 & 5 & C. Van Baalen \\
\hline \multicolumn{3}{|l|}{ Red alga } \\
\hline Porphyridium cruentum & 3 & C. Van Baalen \\
\hline \multicolumn{3}{|l|}{ Brown alga } \\
\hline Petalonia fascia & 8 & Field collected, Port Aransas, Tex., U.S.A. \\
\hline
\end{tabular}

* Organisms were grown in Pyrex test tubes $\left(175 \times 22 \mathrm{~mm}\right.$ ) at 30 or $39^{\circ} \mathrm{C}$ in $20 \mathrm{ml}$ medium (see below) The tubes were bubbled with air enriched with $1 \pm 0 \cdot 1 \%(\mathrm{v} / \mathrm{v}) \mathrm{CO}_{2}$ and illuminated with two F20T12/D lamps placed $8.5 \mathrm{~cm}$ from the growth tubes on either side of the growth bath. The method is essentially a modification of that of Myers (1950). Media and growth temperatures: 1, ASP-2 (Provasoli et al., 1957; Van Baalen, 1962) at $39^{\circ} \mathrm{C}$; 2 , ASP-2 with vitamin $\mathrm{B}_{12}\left(8 \mu \mathrm{g} \mathrm{l}^{-1}\right)$ at $39^{\circ} \mathrm{C} ; 3$, ASP-2 with vitamin $\mathrm{B}_{12}$ $\left(8 \mu \mathrm{g} \mathrm{l}^{-1}\right)$ at $30^{\circ} \mathrm{C} ; 4$, ASP-2 with vitamin $\mathrm{B}_{12}\left(8 \mu \mathrm{g} \mathrm{l}^{-1}\right)$ and vitamin $\mathrm{B}_{1}\left(1 \mathrm{mg} \mathrm{l^{-1 }}\right)$ at $30^{\circ} \mathrm{C} ; 5$, ASP-2 with vitamin $\mathrm{B}_{12}\left(8 \mu \mathrm{gl}^{-1}\right)$, vitamin $\mathrm{B}_{1}\left(1 \mathrm{mg} \mathrm{l}^{-1}\right), \mathrm{NH}_{4} \mathrm{Cl}(1 \mathrm{~mm})$ and $\mathrm{Na}_{2} \mathrm{SiO}_{4} .5 \mathrm{H}_{2} \mathrm{O}\left(375 \mathrm{mg} \mathrm{l}^{-1}\right)$ at $30^{\circ} \mathrm{C}$; $6, \mathrm{Cg}-10$ (Van Baalen, 1967) at $30^{\circ} \mathrm{C}$, supplemented with $0.5 \%(\mathrm{w} / \mathrm{v})$ filter-sterilized glucose for heterotrophic (dark) growth; 7, Cg-10 at $39{ }^{\circ} \mathrm{C}$, supplemented with $0.5 \%(\mathrm{w} / \mathrm{v})$ filter-sterilized glucose for heterotrophic (dark) growth (Bottomley \& Van Baalen, 1978); 8 , filtered seawater $(2 \cdot 5 \%, \mathrm{v} / \mathrm{v})$.

$\dagger$ R. R. Guillard, Woods Hole Oceanographic Institute, Woods Hole, Mass., U.S.A.; J. A. Hellebust, Department of Botany, University of Toronto, Toronto, Canada; J. Myers, Department of Zoology, University of Texas at Austin, Austin, Tex., U.S.A.; R. Rippka, Institut Pasteur, Paris, France; C. Van Baalen, University of Texas Marine Science Institute, Port Aransas Marine Laboratory, Port Aransas, Tex., U.S.A.

Naphthalene, cis- and trans-naphthalene dihydrodiol, 4-hydroxy-1-tetralone and 1-naphthol were cochromatographed with the radioactive metabolites. Each chromatogram was developed as described above. The standard compounds were visualized under ultraviolet light. The chromatogram was then cut into $1.0 \mathrm{~cm}$ strips which were placed in scintillation vials containing $10 \mathrm{ml}$ Aquasol-2 (New England Nuclear). Radioactive metabolites were detected by scintillation counting in a Beckman model LS-250 spectrometer. Metabolites were also detected by autoradiography by exposing the developed chromatograms to Kodak X-ray film (blue-sensitive SB-54) for 2 to 4 weeks.

Analytical methods. Ultraviolet absorption spectra were obtained with a Beckman model 25 recording spectrophotometer. Radiochromatogram tracings were obtained with a Joyce-Loebl densitometer.

Chemicals. Naphthalene (99.95\%) was obtained from Aldrich Chemical Co., Milwaukee, Wis., U.S.A. $\left[1{ }^{14} \mathrm{C}\right] \mathrm{Naph}$ thalene $\left[3.67 \mathrm{mCi} \mathrm{mmol}^{-1}\left(136 \mathrm{MBq} \mathrm{mmol}^{-1}\right)\right]$ was from Amersham/Searle, Arlington Heights, 111., U.S.A. trans-Naphthalene dihydrodiol was a generous gift from L. A. Kapicak, Union Carbide Corp., Charleston, W.V., U.S.A. cis-Naphthalene dihydrodiol was prepared as described previously (Jeffrey et al., 1975). 4-Hydroxy-1-tetralone was also prepared as described previously (Cerniglia \& Gibson, 1977). 1-Naphthol (J. T. Baker Co., Phillipsburg, N.J., U.S.A.) was purified by vacuum sublimation before use. 


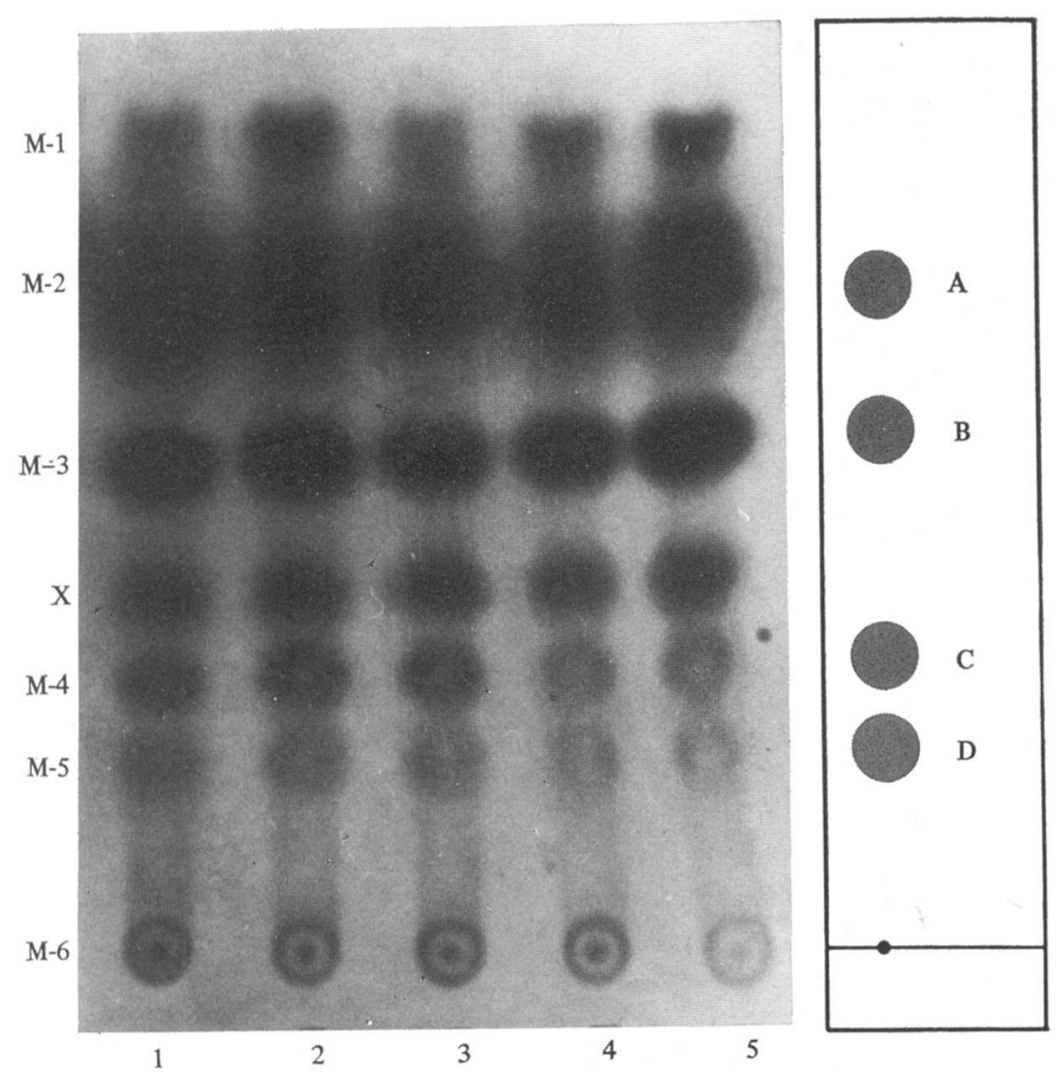

Fig. 1. Autoradiogram of metabolites formed from $\left[1-{ }^{14} \mathrm{C}\right]$ naphthalene by different algae: 1 , Chlorella sorokiniana (green alga); 2, Chlorella autotrophica (green alga); 3, Porphyridium cruentum (red alga); 4, Cylindrotheca sp., strain N-1 (diatom); 5, Amphora sp., strain AMP-1 (diatom). $\mathrm{A}, \mathrm{B}, \mathrm{C}$ and $\mathrm{D}$ show the mobilities of 1-naphthol, 4-hydroxy-1-tetralone, cis-naphthalene dihydrodiol and trans-naphthalene dihydrodiol, respectively. The solvent was chloroform/acetone $(8: 2, v / v)$.

\section{RESULTS AND DISCUSSION}

Eighteen organisms representing five major algal groups were screened for their ability to oxidize naphthalene (Table 1). After $24 \mathrm{~h}$ growth in the presence of naphthalene each culture was analysed for metabolites. All the organisms produced a compound whose chromatographic properties were identical to those of 1-naphthol. This compound gives a characteristic blue-purple colour with Gibb's reagent after exposure to ammonia vapour. Although no attempt was made to identify 1-naphthol by more rigorous criteria, we have reported its conclusive identification as a product formed from naphthalene by Agmenellum quadruplicatum, strain PR-6 (Cerniglia et al., 1979) and Oscillatoria sp., strain JCM (Cerniglia et al., 1980).

In order to quantify the naphthalene oxidation products formed by each organism the experiments were repeated with $\left[{ }^{14} \mathrm{C}\right]$ naphthalene. Autoradiograms were prepared from each thin-layer chromatogram. The results for five organisms representing three of the major groups are shown in Fig. 1. All of the organisms listed in Table 1 gave a similar profile of metabolites. Naphthalene oxidation was not observed in control experiments with heatkilled organisms or in the absence of organisms. In the preceding paper (Cerniglia et al., 1980), we reported the identification of 1-naphthol, 4-hydroxy-1-tetralone and cis-naphthalene dihydrodiol as products formed from naphthalene by Oscillatoria sp., strain JCM; these compounds correspond to the metabolites designated M-2, M-3 and M-4 in Fig. 1 . Thus, it appears that both prokaryotic and eukaryotic algae may form the same metabolic 
Table 2. Quantitative analysis of metabolites formed from $\left[1-{ }^{14} \mathrm{C}\right]$ naphthalene by different species of cyanobacteria and microalgae

Each metabolite from the $\left[1-{ }^{14} \mathrm{C}\right]$ naphthalene incubation was cut from the thin-layer chromatography (t.l.c.) plate and its radioactivity was measured as described in Methods. Metabolite numbers refer to spot numbers in Fig. 1.

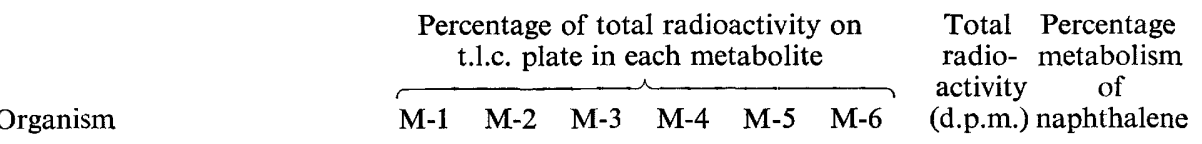

\begin{tabular}{|c|c|c|c|c|c|c|c|c|}
\hline Cyanobacteria & & & & & & & & \\
\hline Oscillatoria sp., strain JCM & 20 & 37 & 20 & 6 & 6 & 11 & 38210 & $2 \cdot 4$ \\
\hline Oscillatoria sp., strain MEV & 64 & 9 & 6 & 4 & 3 & 14 & 4965 & $0 \cdot 3$ \\
\hline Microcoleus chthonoplastes strain BA-1 & 55 & 16 & 5 & 5 & 3 & 16 & 2945 & $0 \cdot 2$ \\
\hline Nostoc sp., strain MAC (light) & 2 & 44 & 28 & 0 & 4 & 22 & 2315 & $0 \cdot 1$ \\
\hline Nostoc sp., strain MAC (dark) & 5 & 23 & 23 & 0 & 40 & 9 & 2795 & $0 \cdot 2$ \\
\hline Anabaena sp., strain CA & 15 & 52 & 18 & 5 & 5 & 6 & 31315 & $2 \cdot 0$ \\
\hline Anabaena sp., strain $1 \mathrm{~F}$ & 17 & 46 & 26 & 4 & 4 & 3 & 24300 & $1 \cdot 5$ \\
\hline Agmenellum quadruplicatum strain PR-6 & 13 & 45 & 25 & 5 & 4 & 10 & 22620 & $1 \cdot 4$ \\
\hline Coccochloris elabens strain $17 \mathrm{a}$ & 0 & 12 & 43 & 28 & 14 & 2 & 32881 & $2 \cdot 0$ \\
\hline Aphanocapsa sp., strain 6714 (light) & 6 & 7 & 51 & 21 & 10 & 4 & 8505 & 0.5 \\
\hline Aphanocapsa sp., strain 6714 (dark) & 21 & 16 & 45 & 12 & 4 & 3 & 11530 & $0 \cdot 7$ \\
\hline Green algae & & & & & & & & \\
\hline Chlorella sorokiniana strain TX 71105 & 8 & 31 & 45 & 8 & 6 & 1 & 18835 & $1 \cdot 2$ \\
\hline Chlorella autotrophica strain 580 & 19 & 36 & 31 & 7 & 5 & 3 & 24785 & $1 \cdot 5$ \\
\hline Dunaliella tertiolecta strain DUN & 9 & 31 & 42 & 11 & 4 & 2 & 15340 & $1 \cdot 0$ \\
\hline Chlamydomonas angulosa & 29 & 37 & 21 & 4 & 4 & 4 & 20045 & $1 \cdot 3$ \\
\hline Ulva fasciata & 13 & 26 & 33 & 8 & 12 & 8 & 18910 & $1 \cdot 2$ \\
\hline Diatoms & & & & & & & & \\
\hline Cylindrotheca sp., strain N-1 & 8 & 38 & 40 & 7 & 5 & 2 & 23165 & $1 \cdot 4$ \\
\hline Amphora sp., strain AMP-1 & 6 & 27 & 44 & 13 & 6 & $\overline{3}$ & 18655 & $1 \cdot 2$ \\
\hline Red alga & & & & & & & & \\
\hline Porphyridium cruentum & 9 & 26 & 44 & 8 & 10 & 2 & 18875 & $1 \cdot 2$ \\
\hline Brown alga & & & & & & & & \\
\hline Petalonia fascia & 13 & 44 & 26 & 4 & 7 & 7 & 29975 & 1.9 \\
\hline
\end{tabular}

products. However, we are aware that chromatographic properties alone are insufficient for firm identification purposes and the exact structures of the metabolites formed by most of the organisms in the present study remain tentative. Nevertheless, it is clear that both prokaryotic and eukaryotic microalgae oxidize naphthalene to several metabolites. The formation of 4-hydroxy-1-tetralone by bacteria (Bollag et al., 1975) and fungi (Cerniglia \& Gibson, 1977, 1978; Cerniglia et al., 1978) has been reported and this product is formed by the further metabolism of 1-naphthol. However, cis-naphthalene dihydrodiol has only been observed as a bacterial metabolite (Jerina et al., 1971; Catterall et al., 1971; Jeffrey et al., 1975). If cis-naphthalene dihydrodiol is formed by eukaryotic algae it will represent the first demonstration of the cis-hydroxylation of naphthalene by higher organisms.

Other metabolites produced by all of the organisms are designated M-1, X, M-5 and M-6 (Fig. 1). The identity of these products remains to be determined. M-1 may be a nonenzymic oxidation product of 1-naphthol, as previously seen with Oscillatoria (Cerniglia et al., 1980). The product M-5 has chromatographic properties similar to those of transnaphthalene dihydrodiol; however, we have shown for Oscillatoria sp., strain JCM (Cerniglia et al., 1980) that M-5 does not resemble trans-naphthalene dihydrodiol when analysed by high-pressure liquid chromatography.

The relative amounts of each metabolite varied according to the organism under investigation (Table 2). This is also clearly demonstrated in densitometer tracings of the autoradiograms obtained after incubating naphthalene with Oscillatoria sp., strain JCM, 


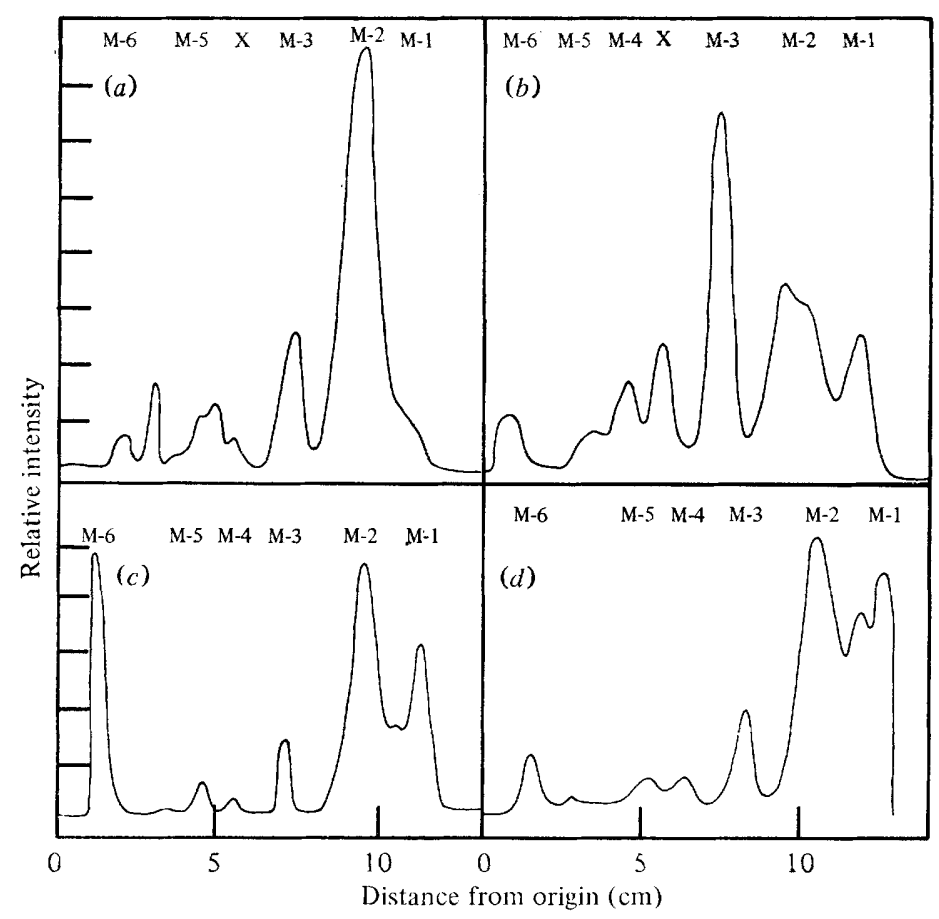

Fig. 2. Radiochromatogram tracings showing metabolites formed from naphthalene by different algae: (a) Oscillatoria sp., strain JCM (cyanobacterium); (b) Porphyridium cruentum (red alga); (c) Petalonia fascia (brown alga); (d) Chlamydomonas angulosa (green alga). M-1 to M-6 represent metabolites shown in Fig. 1.

Porphyridium cruentum, Chlamydomonas angulosa and Petalonia fascia (Fig. 2). The extent of naphthalene metabolism to organic-soluble metabolites ranged from 0.1 to $2.4 \%$ of the total added $\left[{ }^{14} \mathrm{C}\right]$ naphthalene. No attempt was made to quantify the water-soluble products formed by the different organisms; in the case of Oscillatoria sp., strain JCM this amounts to $2 \cdot 8 \%$ (Cerniglia et al., 1980).

It is interesting to note that Chlamydomonas angulosa oxidized naphthalene to several metabolites including 1-naphthol. Soto et al. $(1975 a, b)$ found naphthalene to be extremely toxic and inhibitory to growth of this strain. In addition no metabolic products were detected. The concentrations of naphthalene $(78 \mu \mathrm{M})$ used in the present investigation were not toxic for any of the organisms except the two heterotrophic cyanobacteria Nostoc sp., strain MAC and Aphanocapsa sp. (Hoare et al., 1971; Beauclerk \& Smith, 1978; Bottomley $\&$ Van Baalen, 1978). These were extremely sensitive to naphthalene concentrations above $10 \mu \mathrm{M}$ as shown by obvious bleaching of photosynthetic pigments after a few hours. Both organisms oxidized naphthalene to a slight extent under both dark and light conditions. The significance of these results remains to be investigated. Anabaena sp., strain CA, a marine filamentous cyanobacterium capable of rapid growth under nitrogen-fixing conditions (Stacey et al., 1977), and Anabaena sp., strain 1F, also a nitrogen-fixing cyanobacterium, oxidized naphthalene (Table 2).

The ability of algae to metabolize aromatic compounds has been reported previously. Thus, Ellis (1977) showed that ${ }^{14} \mathrm{CO}_{2}$ was formed from $\left[{ }^{14} \mathrm{C}\right]$ catechol by six algal strains, and four of these organisms also metabolized phenol to $\mathrm{CO}_{2}$. However, we believe that the results presented in this paper represent the first demonstration that the ability to oxidize aromatic hydrocarbons is widespread in the algal kingdom. These observations could have profound implications for the fate and effects of this class of compounds in the environment. 
This investigation was supported by grant no. ES-00537 awarded by the Institute of Environmental Health Sciences, D.H.E.W. C.E.C. is a postdoctoral trainee supported by grant no. T32 CA09182 awarded by the National Cancer Institute, D.H.E.W. We thank Rita O'Donnell and Joseph C. Morgan for technical assistance and Roberta De Angelis for assistance in preparing the manuscript.

\section{REFERENCES}

Beauclerk, A. A. D. \& Smith, A. J. (1978). Transport of D-glucose and 3-O-methyl-Dglucose in the cyanobacteria Aphanocapsa 6714 and Nostoc strain MAC. European Journal of Biochemistry 82, 187-188.

Bollag, J. M., Czaplicki, E. J. \& Minard, R. D. (1975). Bacterial metabolism of 1-naphthol. Agricultural and Food Chemistry 23, 85-90.

Bottomley, P. J. \& Van BaAlen, C. (1978). Dark hexose metabolism of photoautotrophically and heterotrophically grown cells of the blue-green alga (cyanobacterium) Nostoc sp., strain MAC. Journal of Bacteriology 135, 888-894.

Catterall, F. A., Murray, K. \& Williams, P. A. (1971). The configuration of the 1,2-dihydroxy1,2-dihydronaphthalene formed in the bacterial metabolism of naphthalene. Biochimica et biophysica acta 237, 361-364.

Cerniglia, C. E. \& Gibson, D. T. (1977). Metabolism of naphthalene by Cunninghamella elegans. Applied and Environmental Microbiology 34, 363 370.

Cerniglia, C. E. \& Gibson, D. T. (1978). Metabolism of naphthalene by cell extracts of Cunning. hamella elegans. Archives of Biochemistry and Biophysics 186, 121-127.

Cerniglia, C. E., Hebert, R. L., Szaniszlo, P. J. \& GiBson, D. T. (1978). Fungal transformation of naphthalene. Archives of Microbiology 117, 135143.

Cerniglia, C. E., Gibson, D. T. \& Van BaAlen, C. (1979). Algal oxidation of aromatic hydrocarbons: formation of 1-naphthol from naphthalene by Agmenellum quadruplicatum, strain PR-6. Biochemical and Biophysical Research Communications 88, 50-58.

Cerniglia, C. E., Van Baalen, C. \& Gibson, D. T. (1980). Metabolism of naphthalene by the cyanobacterium Oscillatoria sp., strain JCM. Journal of General Microbiology 116, 485-494.

Daly, J. W., Jerina, D. M. \& WiTkop, B. (1972). The metabolism, toxicity and carcinogenicity of aromatic compounds. Experientia 28, 1129-1149.

Ellis, B. E. (1977). Degradation of phenolic compounds by fresh-water algae. Plant Science Letters 8, 213-216.

Hoare, D. S., Ingram, L. O., Thurston, E. L. \&
WaLKUP, R. (1971). Dark heterotrophic growth of an endophytic blue-green alga. Archiv für Mikrobiologie 78, 310-321.

JefFrey, A. M., YeH, H. J. C., JeRina, D. M., Patel, T. R., DaveY, J. F. \& Gibson, D. T. (1975). Initial reactions in the oxidation of naphthalene by Pseudomonas putida. Biochemistry 14, 575-584.

Jerina, D. M., DALY, J. W., JefFrey, A. M. \& GiBson, D. T. (1971). cis-1,2-Dihydroxy-1,2dihydronaphthalene: a bacterial metabolite from naphthalene. Archives of Biochemistry and Biophysics 142, 394-396.

MYeRS, J. (1950). The culturing of algae for physiological research. In The Culturing of Algae, pp. 45-51. Edited by J. Brunel, G. W. Prescott \& L. H. Tiffany. Yellow Springs, Ohio, U.S.A.: Charles F. Kettering Foundation.

Provasoli, L., Mclaughlin, J. J. \& Droop, M. R. (1957). The development of artificial media for marine algae. Archiv für Mikrobiologie 25, 392428.

Soto, C., Hellebust, A. J., Hutchinson, T. C. \& SAWA, T. (1975a). Effect of naphthalene and aqueous crude oil extracts on the green flagellate Chlamydomonas angulosa. I. Growth. Canadian Journal of Microbiology 53, 109-117.

Soto, C., Hellebust, A. J. \& Hutchinson, T. C. $(1975 b)$. Effect of naphthalene and aqueous crude oil extracts on the green flagellate Chlamydomonas angulosa. II. Photosynthesis and the uptake and release of naphthalene. Canadian Journal of Microbiology 53, 118-126.

Stacey, G., Van BaAlen, C. \& Tabita, F. R. (1977). Isolation and characterization of a marine Anabaena sp. capable of rapid growth on molecular nitrogen. Archives of Microbiology 114, 197-201.

VAN BaAlen, C. (1962). Studies on marine bluegreen algae. Botanica marina 4, 129-139.

VAN BaAlen, C. (1967). Further observations on growth of single cells of coccoid blue-green algae. Journal of Phycology 3, 154-157.

Winters, K., O'Donnell, R., Batterton, J. C. \& VAN BAALEN, C. (1976). Water soluble components of four fuel oils: chemical characterization and effects on growth of microalgae. Marine Biology 36, 269-276. 